\title{
PERANCANGAN CARD GAME MENGENAL PLASTIK UNTUK ANAK USIA 9-12 TAHUN DENGAN MEKANIK MEMORY
}

\author{
Laurensius Ricky Kristanto ${ }^{1}$, Jasson Prestiliano ${ }^{2}$, T. Arie Setiawan Prasida ${ }^{3}$ \\ ${ }^{1,2,3}$ Progdi Desain Komunikasi Visual, Fakultas Teknologi Informasi, Universitas Kristen Satya Wacana \\ larrylian94@gmail.com ${ }^{1}$, jasprelao@gmail.com ${ }^{2}$, arie.setiawan.p@gmail.com ${ }^{3}$
}

\begin{abstract}
Abstrak
Indonesia merupakan salah satu penyumbang sampah plastik terbesar di dunia. Sampah plastik adalah sampah anorganik yang sulit terurai dan mencemari lingkungan. Plastik diklarifikasikan menjadi tujuh jenis tingkatan dan memiliki karakternya masing-masing. Peringatan akan bahaya sampah plastik yang ada, dianggap hanya bisa dipahami oleh orang dewasa saja. Supaya anakanak dapat lebih mengenal plastik, dipilihlah media permainan sebagai media pembelajaran yang dapat lebih menarik untuk anak-anak. Penelitian ini bertujuan untuk mengenalkan jenisjenis plastik yang ada kepada anak-anak sejak dini, supaya plastik dapat lebih dikenal oleh anakanak. Metode yang digunakan adalah metode penelitian campuran yang memadukan pendekatan kualitatif dan kuantitatif dengan strategi linier. Metode perancangan permainan melalui tahapan konsep, uji coba, tahapan desain, prototyping, uji coba, dan produksi permainan. Hasil akhir dari penelitian ini adalah permainan kartu dengan mekanisme permainan yang mengandalkan daya ingat. Mekanisme tersebut digunakan untuk membentuk kebiasaan baik sejak dini dan merangsang daya ingat anak yang sedang berkembang. Penelitian ini mampu membuat anak-anak untuk lebih mengenal jenis-jenis plastik yang ada beserta sifatnya, dan menjadi media pembelajaran yang menyenangkan bagi anak-anak.
\end{abstract}

Kata Kunci: plastik, permainan kartu, edukasi, memori

\begin{abstract}
Indonesia is one of the largest plastic waste contributors in the world. Plastic waste is inorganic waste that is difficult to decompose and pollute the environment. Plastics are clarified into 7 types of levels and have their characters. Warnings of the dangers of plastic waste are considered only to be understood by adults. For children to get to know plastics, the game is chosen as a learning medium that can be more interesting for children. This research aims to introduce the types of plastic available to children from an early age, so that plastic can be better known by children. The method used is a mixed method that combines qualitative and quantitative approaches with a linear strategy. The method of designing a game through the concept phase, playtesting, design phase, prototyping, playtesting, and game production. The final result of this research is a card game with a mechanism that relies on memory. The mechanism is used to form good habits from an early age and stimulate the memory of children. This research can make children more familiar with the types of plastic that exist and their characters, and become an exciting learning media for children.
\end{abstract}

Keywords: plastic, card game, education, memory 


\section{PENDAHULUAN}

Sampah merupakan material sisa yang berasal dari manusia, hewan, maupun tumbuhan dalam bentuk padat, cair, maupun gas yang dibuang karena sudah tidak terpakai lagi. Berdasarkan sifatnya, sampah dibagi menjadi dua jenis yaitu pertama adalah sampah organik. Sampah organik merupakan sampah yang dapat mengalami pembusukan atau pelapukan. Jenis yang kedua adalah sampah anorganik yaitu sampah yang sangat sulit terurai. Sampah plastik tergolong dalam kategori sampah anorganik yang sulit terurai dan mencemari lingkungan. Indonesia menduduki peringkat kedua, setelah Tiongkok, untuk persoalan sampah plastik. Produksi sampah plastik Indonesia mencapai 5,4 juta ton per tahun. Jumlah sampah plastik tersebut merupakan $14 \%$ dari total produksi sampah di Indonesia, dan didominasi oleh sampah plastik domestik. Plastik yang tidak terkelola dan menumpuk dapat merusak lingkungan dan mengancam kesehatan masyarakat (Syafputri, 2014).

Kesadaran masyarakat akan bahaya sampah plastik yang dikelola secara buruk sangatlah penting. Namun hal ini tidak cukup untuk benar-benar mengurangi ketergantungan pada penggunaan plastik sekali pakai. Untuk memerangi perang dengan limbah plastik, pemerintah pusat dan daerah harus memperkuat kerangka hukum. Perlu ada definisidefinisi yang digunakan secara nasional untuk membedakan berbagai jenis plastik. Diperlukan kejelasan mengenai tanggung jawab di setiap tingkat pemerintahan dan pembuatan norma-norma baru, standar, prosedur, dan kriteria (Wright, 2017).

Plastik sendiri diklarifikasikan menjadi 7 jenis tingkatan, mulai dari kode symbol angka 1-7. Plastik dengan kode 1 atau PET (Polyethylene Terephthalate) merupakan plastik yang bersifat transparan dan jernih. Plastik jenis ini biasa ditemui pada botol air mineral, dan dianjurkan hanya untuk sekali pakai. Plastik dengan kode 2 atau HDPE (High-Density Polyethylene) tergolong aman untuk digunakan karena kemampuannya mencegah reaksi kimia antara kemasan dan makanan atau minuman di dalamnya. Plastik jenis ini biasa digunakan sebagai botol obat, dan dianjurkan hanya untuk sekali pakai karena penggunaan secara berkala dapat melepaskan senyawa antimoni trioksida. Plastik dengan kode 3 atau PVC (Polyvinyl Chloride) memiliki ketahanan terhadap bahan kimia, minyak, dan memiliki ketahanan dengan titik leleh $70-140^{\circ} \mathrm{C}$. Plastik jenis ini tergolong sulit untuk didaur ulang, dan biasa digunakan sebagai pipa. Plastik dengan kode 4 atau LDPE (Low-Density Polyethylene) merupakan plastik yang kuat, dan sulit terurai, plastik ini juga bisa digunakan untuk kemasan makanan. Plastik ini dapat didaur ulang untuk barang-barang yang membutuhkan fleksibilitas dan memiliki resistensi yang baik terhadap reaksi kimia. Plastik dengan kode 5 atau PP (Polypropylene) biasa digunakan sebagai tempat penyimpanan makanan dan minuman. Plastik ini bersifat kuat, ringan, memiliki ketahanan terhadap lemak dan memiliki ketahanan dengan titik leleh $165^{\circ} \mathrm{C}$. Plastik dengan kode 6 atau PS (Polystyrene) mempunyai kekakuan, dan kestabilan dimensi yang baik. Plastik ini biasa digunakan untuk tempat makanan sekali pakai, hanya saja hal itu tidak terlalu dianjurkan. Karena plastik ini kurang tahan terhadap suhu tinggi, dan sulit untuk didaur ulang. Plastik dengan kode 7 atau OTHER merupakan plastik yang sudah dicampur dengan bahan lain, dan biasa dibuat menjadi peralatan rumah tangga (Karuniastuti, 2013). 
Penelitian yang ditulis oleh Widodo dengan judul "Iklan Layanan Masyarakat Bahaya Sampah Plastik". Dalam penelitian tersebut menyatakan bahwa sampah plastik bisa mencemari lingkungan dan mengancam kelangsungan hidup manusia. Terutama sampah plastik yang tidak mudah terurai dan membutuhkan waktu yang sangat lama untuk bisa terurai oleh alam. Oleh sebab itu perlu diambil tindakan untuk menanggulangi masalah sampah plastik. Meskipun sudah disebar peringatanperingatan tantang bahaya sampah melalui media cetak maupun elektronik, hal tersebut dianggap kurang karena hanya dipahami oleh orang dewasa saja. Oleh karena ini dibuat iklan dengan bentuk animasi yang menggunakan karakter kartun yang disukai anak-anak. Sehingga anak-anak mulai dari sekolah dasar sudah mengerti betapa bahayanya sampah plastik bagi kehidupan (Widodo, 2014).

Hal tersebut tidak lepas dari dunia anak yang merupakan dunia bermain dan belajar dengan melibatkan seluruh indra anak. Bermain adalah kegiatan yang dipilih sendiri oleh anak karena terasa menyenangkan. Melalui permainan anak-anak dapat mengembangkan seluruh potensinya secara maksimal, baik potensi fisik, mental intelektual, dan spiritual (Sudarsana, 2017). Sehingga penelitian ini bertujuan untuk mengedukasi anak-anak mengenai jenis-jenis plastik yang ada, beserta sifat-sifatnya, dan membuangnya dengan cara yang benar. Anak-anak akan belajar mengenal jenis plastik dengan permainan yang menyenangkan. Diharapkan media pembelajaran seperti ini dapat lebih menarik minat anak untuk mempelajari sesuatu. Usia 9 tahun adalah usia yang tepat untuk membentuk kebiasaan baik dalam diri anak-anak. Secara mental, anak dalam usia ini sedang gemar-gemarnya membaca, memiliki daya ingat yang tajam dan baik, dan mulai berpikir logis (Setiawani, 2001).

Hal ini senada dengan penelitian yang ditulis oleh Hijriati dengan judul "Peranan dan Manfaat APE (Alat Permainan Edukatif) untuk Mendukung Kreativitas Anak Usia Dini" menyatakan bahwa permainan edukatif adalah alat bermain yang merangsang aktivitas anak untuk mempelajari sesuatu tanpa anak menyadarinya, baik menggunakan teknologi modern maupun tradisional. Aktivitas bermain pada anak-anak ditujukan untuk mengembangkan kemampuan fisik-motorik, sosial-emosional, dan kecerdasan. Permainan edukatif berfungsi untuk melatih konsentrasi, mengajar dengan lebih cepat, mengatasi keterbatasan waktu, mengatasi keterbatasan tempat, mengatasi keterbatasan bahasa, membangkitkan emosi, menambah daya pengertian, menambah daya ingat, memberikan kesegaran dalam mengajar (Hijriati, 2017).

Untuk memaksimalkan daya ingat anak yang sedang tajam pada usia tersebut, permainan ini dirancang dengan menggunakan mekanik memory. Board game dan card game terasa lebih menyenangkan dan berkualitas dibandingkan dengan memainkan gadget atau game console yang cenderung bersifat individualis. Permainan ini dapat menjadi sarana yang baik bagi anak untuk belajar berkomunikasi, menghitung nilai, mengambil keputusan, jujur dan sportif dalam bermain (Wirawan, 2015). Penelitian yang ditulis oleh Christian dengan judul "Developing Board Game as Learning Media about waste sorting for Fourth Grade Students of Elementary School" menyatakan bahwa media pembelajaran yang biasa digunakan di sekolah adalah buku. Tidak semua 
murid dapat memahami informasi dari buku tersebut. Metode guru yang menerangkan dan murid yang mendengarkan membuat murid tidak dapat berkonsentrasi secara menyeluruh. Dibutuhkan media pembelajaran yang menarik dan cocok dengan gaya belajar anak-anak yaitu salah satunya dengan board game (Christian, 2018).

Penelitian lainnya yang ditulis oleh Jordi dengan judul "Perancangan Board Game Edukatif Tentang Peduli Lingkungan Untuk Anak Usia 7 - 12 Tahun" menyatakan bahwa bermain merupakan hal yang tidak bisa dipisahkan dari anak-anak, dan menjadi kegiatan yang rutin dilakukan anak-anak. Board Game dipilih karena memiliki beberapa keunggulan seperti: aturan yang membuat anak-anak belajar untuk menaati peraturan yang ada, belajar kedisiplinan, dan memicu interaksi sosial dengan pemain lainnya (Jordi, 2017).

Berdasarkan penelitian terdahulu yang telah dipaparkan, penelitian ini diharapkan memberi nuansa baru dan menyenangkan sebagai media edukasi untuk anak-anak. Khususnya sebagai media edukasi pengenalan jenis-jenis plastik yang dibutuhkan dalam skala nasional dan menjangkau anak-anak supaya lebih mudah memahami. Anak-anak memiliki kesenangan untuk bermain, dalam APE bisa menggunakan berbagai jenis media baik yang tradisional maupun modern. Salah satu media modern yang dapat digunakan untuk mendukung kegiatan pembelajaran anak adalah board game. Card game sendiri merupakan salah satu jenis board game, maka dari itu media card game bisa dipilih untuk menarik minat anak dalam mempelajari jenis-jenis plastik yang ada.

\section{METODE PENELITIAN}

Metode yang digunakan dalam penelitian ini adalah metode penelitian campuran. Metode campuran adalah metode yang memadukan pendekatan kualitatif dan kuantitatif dalam hal metodologi (seperti dalam tahap pengumpulan data), dan kajian model campuran memadukan dua pendekatan dalam semua tahapan proses penelitian. Metode campuran adalah sebuah metodologi yang memberikan asumsi filosofis dalam menunjukkan arah atau memberi petunjuk cara pengumpulan data dan menganalisis data serta perpaduan pendekatan kuantitatif dan kualitatif melalui beberapa fase proses penelitian. Metode campuran yang digunakan adalah urutan analisis kuantitatif dan kualitatif, tujuan strategi ini adalah untuk mengidentifikasi komponen konsep melalui analisis data kuantitatif dan kemudian mengumpulkan data kualitatif guna memperluas informasi yang tersedia (Sugiyono, 2014).

Tahapan perancangan dalam penelitian ini menggunakan linear strategy atau strategi garis lurus yang menempatkan ukuran logis pada tahapan yang sederhana dan mudah dipahami komponenya (Sarwono, 2007). Tahapan perancangan dengan linear strategy dapat dilihat pada Gambar 1.

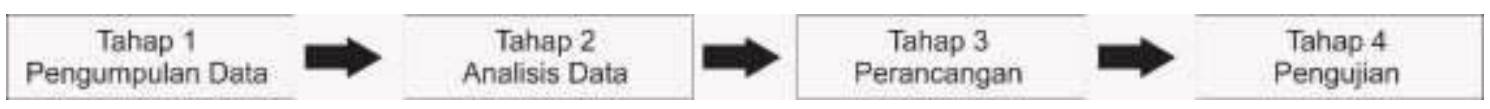

Gambar 1. Tahap perancangan dengan menggunakan linear strategy

[Sumber: Dokumentasi Sarwono, 2007] 
Pada tahap pertama, dilakukan pengumpulan data. Data diperoleh dari responden yang dipilih, responden dalam penelitian ini adalah murid kelas V SDN 8 Salatiga. Responden berjumlah 22 anak yang diberikan kuisioner mengenai pemahaman akan board game dan plastik. Setelah itu data akan dianalisis menggunakan skala Likert. Skala Likert adalah suatu skala psikometrik yang umum digunakan dalam angket dan merupakan skala yang paling banyak digunakan dalam riset berupa survei (Likert, 1932). Responden akan memilih nilai dari sangat positif sampai dengan sangat negatif yang dapat berupa kata-kata antara lain: sangat setuju, setuju, ragu-ragu, tidak setuju, dan sangat tidak setuju. Pada kuisioner pertama diajukan pertanyaan seputar board game dengan pilihan tidak pernah, jarang, sering, dan sering sekali. Skor tertinggi pada kuisioner pertama adalah pilihan tidak pernah dengan skor 4, jarang dengan skor 3, sering dengan skor 2, dan sangat sering dengan skor 1 . Pada kuisioner kedua skor tertinggi adalah pilihan sangat setuju dengan 5 skor, setuju dengan 4 skor, ragu-ragu dengan 3 skor, tidak setuju dengan 2 skor, dan sangat tidak setuju dengan 1 skor. Penghitungan dilakukan dengan cara membagi hasil skor dengan akumulasi nilai tertinggi (jumlah responden dikalikan dengan skor tertinggi), lalu dikalikan $100 \%$. Beberapa pertanyaan dengan pilihan terbatas akan dihitung persentasenya dengan cara jumlah dibagi jumlah total, lalu dikalikan $100 \%$. Adapun data kualitatif didapatkan dengan cara wawancara dengan wali kelas V SDN 8 Salatiga, Munawiati.

Adapun hasil dari wawancara dengan Munawiati, wali kelas V SDN 8 Salatiga menyatakan bahwa SDN 8 Salatiga merupakan piloting pendidikan keluarga. Muridmurid ditanamkan sopan santun, tata karma, dan kedisiplinan di sekolah ini. Hal inilah yang membuat murid-murid terbiasa untuk membuang sampah pada tempatnya, memberi senyum dan sapa, dan juga berdoa di sekolah. SDN 8 Salatiga belum pernah menggunakan game sebagai media pembelajaran alternatif, SDN 8 hanya sebatas menggunakan power point dan film sebagai media alternatif selain buku dan papan tulis. Responden dipilih karena SDN 8 Salatiga belum pernah menggunakan game sebagai media pembelajaran alternatif, dan beberapa responden belum pernah memainkan board game. SDN 8 Salatiga juga berharap untuk dapat mencoba game sebagai media pembelajaran kreatif untuk menunjang proses belajar mengajar.

Pada tahap perancangan dalam penelitian ini dilakukan beberapa proses sebelum nantinya permainan akan diujikan kepada responden. Tahap pertama adalah concepting phase, kemudian dilakukan play test untuk dapat masuk ke dalam design phase. Setelah itu dibuatlah prototype untuk uji coba permainan dan masuk ke tahap produksi jika permainan sudah dianggap layak untuk dimainkan. Proses perancangan dilakukan berdasarkan konsep game design oleh Kummara. Proses game design terdapat pada Gambar 2.

Dalam tahap pertama dilakukan pembuatan konsep. Konsep awal yang dirancang adalah tujuan permainan, latar permainan, mekanik permainan, aturan dasar permainan, serta cerita permainan. Konsep tersebut berdasarkan oleh elemen-elemen dasar perancangan permainan yang nantinya akan dikembangkan dan disempurnakan (Tangidy, 2016). 


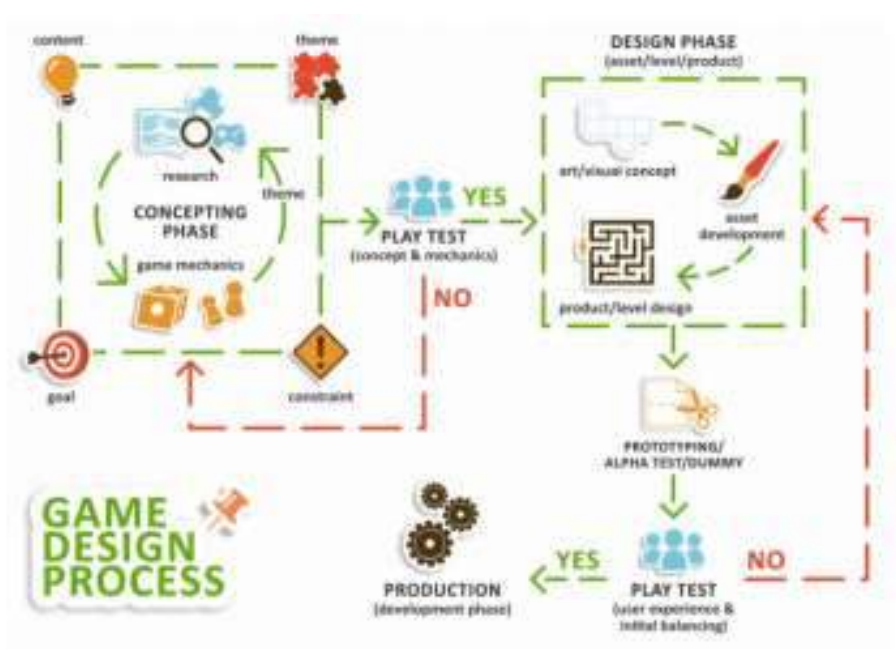

Gambar 2. Game Design Process

[Sumber: Dokumentasi Kummara, 2013]

Tujuan utama dari permainan ini adalah mengumpulkan kartu plastik sebanyakbanyaknya untuk mendapatkan point untuk mencapai kemenangan. Pemain harus mengenal sifat-sifat yang sesuai dengan jenis plastik tertentu untuk dapat mendapatkannya. Permainan akan selesai saat semua kartu plastik sudah habis terambil pemain. Latar permainan ini adalah fantasi, penggunaan latar tersebut untuk merangsang daya imajinasi anak-anak. Jenis-jenis plastik yang ada akan dihidupkan menjadi karakter kartun untuk menjadi daya tarik bagi anak-anak. Mekanik yang digunakan adalah memory dengan sistem permainan kompetitif. Mekanik tersebut digunakan untuk merangsang daya ingat anak-anak dan bertujuan agar jenis plastik beserta sifatnya menjadi lebih mudah untuk diingat. Sistem kompetitif dipilih untuk menghadirkan persaingan antar pemain supaya tiap pemain berusaha mengeluarkan kemampuan terbaiknya untuk memenangkan permainan.

Konsep aturan dasar permainan ini adalah dengan mengingat posisi kartu yang tepat. Pemain akan membuka satu kartu plastik yang masih tersedia untuk dimainkan dan membuka kartu sifat untuk mencari sifat yang sesuai dengan kartu plastik yang telah dibuka. Jika sifat yang dipilih sesuai, maka pemain boleh membuka kartu sifat lainnya.

Cerita dari permainan ini bermula dari seorang anak bernama Nino yang hendak mengisi ulang air di botol PET yang sudah digunakan selama beberapa hari. Kemudian datanglah teman Nino yang bernama Lily, Lily datang dan menegur Nino karena melihat botol yang sudah digunakan berkali-kali tersebut. Selanjutnya botol plastik yang digenggam oleh Nino berubah menjadi hidup dan menegur Nino. Botol tersebut mengajak Nino untuk berkenalan dengan plastik-plastik lainnya.

Setelah konsep-konsep tersebut dirancang, akan dilakukan playtest untuk melihat kecocokan konsep yang dipilih dengan permainan. Tahapan ini akan dilakukan sampai konsep permainan sudah cocok dengan tujuan penelitian, yaitu memperkenalkan plastik pada anak-anak. 
Tahap selanjutnya adalah design phase. Dalam tahapan ini, konsep yang sudah ditentukan akan dirancang ilustrasinya. Ilustrasi yang akan dirancang adalah karakter, ikon, dan layout kartu. Setelah perancangan selesai, dibuatlah prototype untuk melakukan playtest untuk menguji jalannya dan keseimbangan permainan. Contoh dari prototype awal permainan dapat dilihat pada Gambar 3.

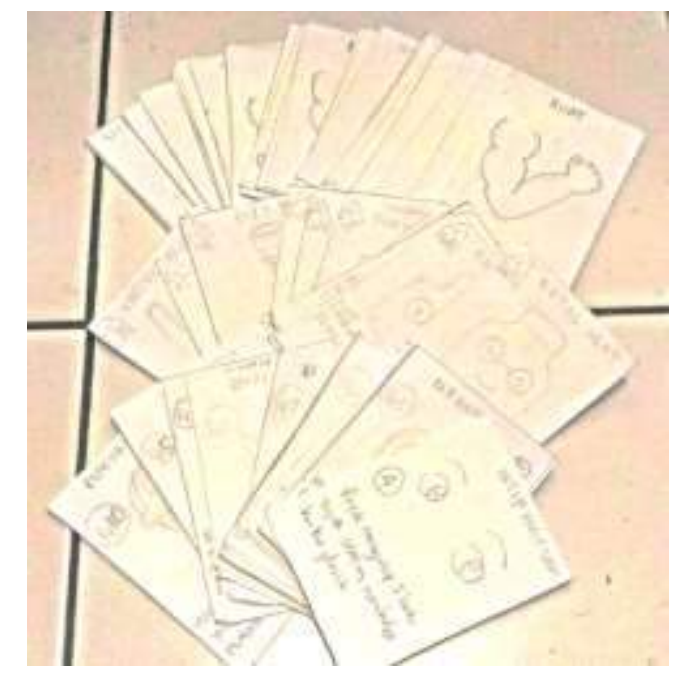

Gambar 3. Prototype awal permainan [Sumber: Dokumentasi Laurensius, dkk]

Setelah prototype sudah selesai, tahap selanjutnya adalah melakukan playtest dengan ahli dalam bidangnya. Dalam penelitian ini, playtest dilakukan bersama dengan Erwin Skripsiadi salah satu penggiat industri board game dan CEO dari Hompimpa Games. Untuk memaksimalkan konsep permainan, dan menyeimbangkan permainan. Menurut Erwin Skripsiadi, "Permainan ini sudah unik dan menarik untuk anak-anak, penggunaan kartu spesial menambahkan unsur keunikan untuk kompetisi. Kekurangannya adalah pemain pertama harus menjadi "tumbal" untuk membuka permainan, alangkah baiknya kalau giliran pemain dapat diubah supaya permainan menjadi lebih seimbang". Setelah playtest selesai, selanjutnya akan dilakukan development phase.

Dalam development phase, prototype yang sudah baik akan dikembangkan untuk menjadi prdouk akhir. Pengembangan yang dilakukan adalah pengembangan ilustrasi untuk memaksimalkan hasil akhir dari prototype yang masih berupa gambar tradisional menjadi gambar digital. Setelah ilustrasi digital selesai, tahap selanjutnya adalah pemberian judul permainan. Judul yang dipilih untuk permainan ini adalah "Teman Plastik" . Judul ini digunakan untuk merepresentasikan permainan yang bertujuan untuk lebih mengenal plastik lebih dekat supaya pemain dapat berteman dengan plastikplastik yang ada. Setelah itu permainan akan memasuki tahap produksi, permainan akan dicetak dan siap untuk diujikan kepada responden. Contoh tahapan proses ilustrasi dapat dilihat pada Gambar 4. 

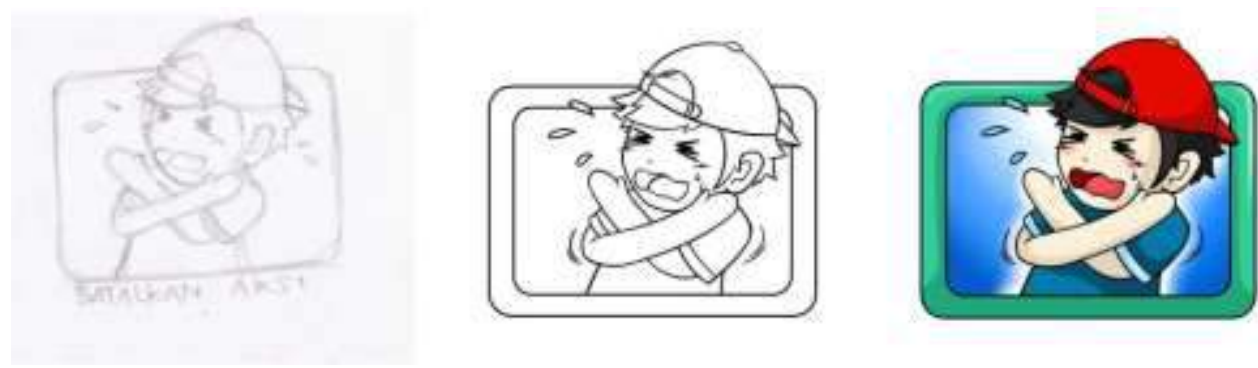

Gambar 4. Contoh tahapan proses ilustrasi permainan Teman Plastik

[Sumber: Dokumentasi Laurensius, dkk]

\section{HASIL DAN PEMBAHASAN}

Terdapat beberapa komponen dalam permainan Teman Plastik. Komponen pertama adalah rulebook. Dalam rulebook Teman Plastik terdapat cerita latar belakang permainan, objektif permainan, komponen permainan, persiapan permainan, peraturan permainan, penjelasan kartu spesial, akhir permainan, dan penjelasan easy mode. Rulebook dibuat dengan gaya komik supaya anak-anak lebih tertarik untuk membaca dan memahami peraturan. Contoh rulebook dapat dilihat pada Gambar 5.
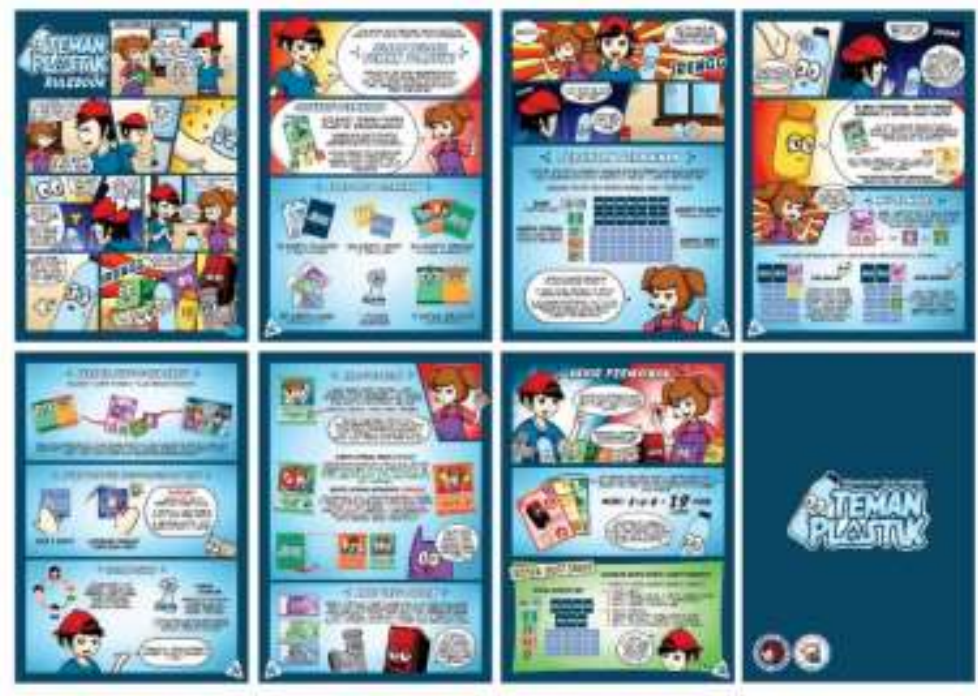

Gambar 5. Hasil akhir rulebook dalam permainan Teman Plastik [Sumber: Dokumentasi Laurensius, dkk]

Selanjutnya terdapat 5 jenis kartu sifat dengan jumlah kartu sebanyak 36 kartu. Kartu sifat dalam permainan Teman Plastik mencakup kartu tahan panas, sukar didaur ulang, sekali pakai, kuat, dan foodgradable. Kartu tahan panas berjumlah sebanyak 6 kartu, sukar didaur ulang sebanyak 4 kartu, sekali pakai sebanyak 8 kartu, kuat sebanyak 8 kartu, dan foodgradable sebanyak 10 kartu. Jumlah tersebut telah disesuaikan dengan kartu plastik yang ada, kartu sifat sudah dirancang untuk habis dalam permainan dan berdampingan bersama kartu plastik lainnya. Pemain harus menemukan sifat yang sesuai dengan kartu plastik yang dimainkan untuk mendapatkan kartu plastik dan kartu sifat tersebut. Contoh kartu sifat dapat dilihat pada Gambar 6. 


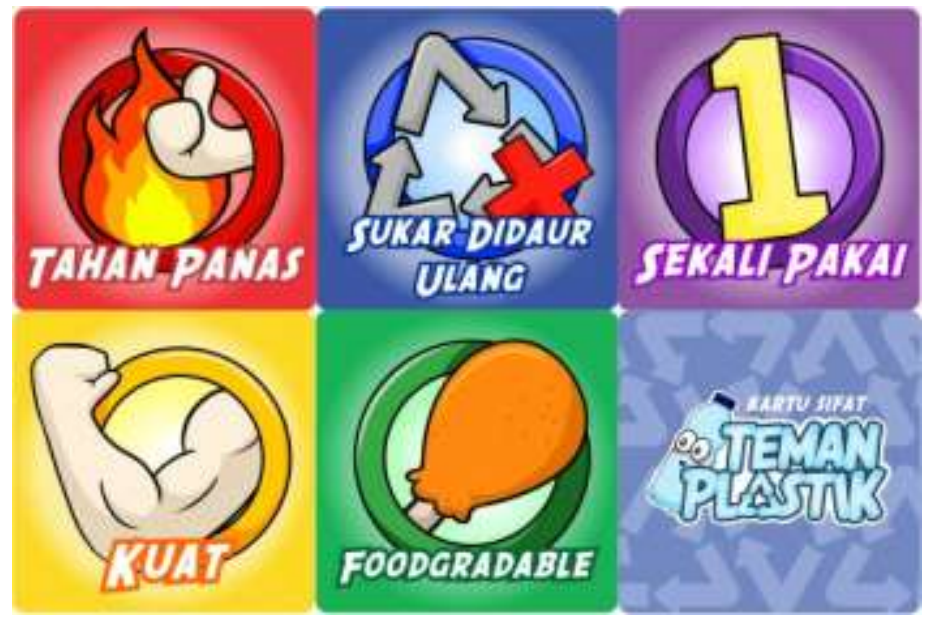

Gambar 6. Hasil akhir kartu sifat dalam permainan Teman Plastik [Sumber: Dokumentasi Laurensius, dkk]

Komponen selanjutnya dalam permainan Teman Plastik adalah kartu plastik. Dalam kartu plastik terdapat ilustrasi mengenai contoh plastik berdasarkan jenisnya, sifat-sifat plastik tersebut, dan skor serta nilai uang kartu tersebut. Jenis-jenis plastik yang ada dalam permainan Teman Plastik merupakan plastik PET, HDPE, PVC, LDPE, PP, PS, dan OTHER. Terdapat 14 kartu plastik dan 7 jenis plastik, terdapat 2 kartu untuk masingmasing jenisnya. Dalam setiap kartu plastik terdapat 2-3 sifat yang harus dicocokkan dengan kartu sifaat yang sesuai. Jumlah kartu tersebut dirancang untuk memberikan tantangan lebih kepada pemain, adapun easy mode hanya menggunakan 7 kartu plastik untuk dimainkan jika 14 kartu terasa sulit untuk dimainkan anak-anak. Mode tersebut dirancang karena pada usia 6 - 12 tahun rentang konsentrasi anak berkisar antara 3045 menit karena mereka sudah memiliki semangat berkompetisi yang tinggi dan rasa ingin tahu yang besar (Wawa, 2012). Easy mode menjadi antisipasi jika anak merasa permainan terlalu sulit dan menjadi membosankan karena durasi bermain yang lama. Contoh kartu plastik dapat dilihat pada Gambar 7.

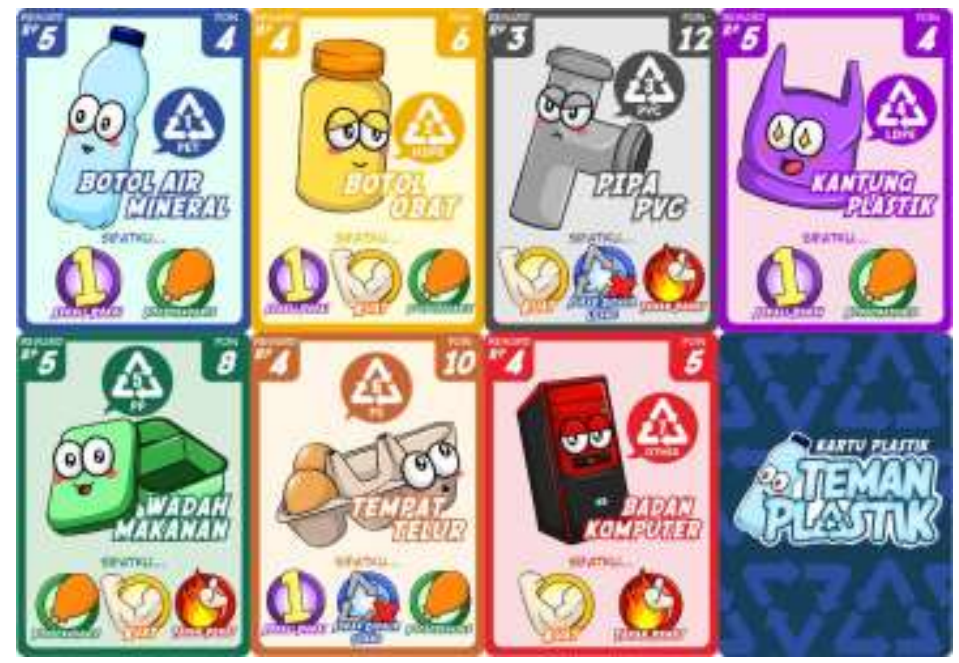

Gambar 7. Hasil akhir kartu plastik dalam permainan Teman Plastik [Sumber: Dokumentasi Laurensius, dkk] 
Komponen berikutnya adalah kartu spesial. Kartu spesial memungkinkan pemain untuk mendapatkan kemampuan khusus yang bisa berdampak terhadap diri sendiri atau pemain lainnya. Untuk mendapatkan kartu spesial, pemain harus membeli kartu tersebut sesuai dengan harga yang tertera pada kartu. Terdapat 2 jenis kartu spesial dalam permainan Teman Plastik, kartu dengan latar belakang hijau dan merah. Kartu dengan latar hijau hanya dapat digunakan saat giliran pemilik kartu tersebut, sedangkan kartu dengan latar merah dapat digunakan kapanpun (kecuali pemain terkena efek kartu tutup mata). Terdapat 9 jenis kartu spesial dengan harga yang berbeda-beda dan kemampuan yang berbeda-beda dengan jumlah kartu sebanyak 20. Terdapat 2 buah kartu tutup mata, 1 kartu pemulung, 1 kartu main 2 plastik, 3 kartu intip kartu, 2 kartu main 2 kali, 4 kartu batalkan aksi, 3 kartu interupsi, 2 kartu acak kartu, dan 2 kartu berhenti. Contoh kartu spesial dapat dilihat pada Gambar 8.

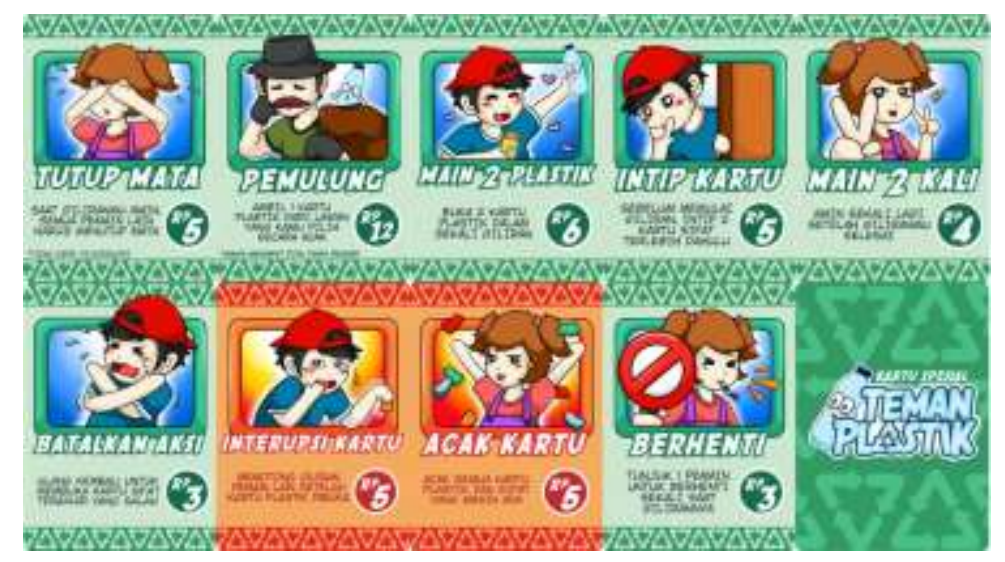

Gambar 8. Hasil akhir kartu spesial dalam permainan Teman Plastik

[Sumber: Dokumentasi Laurensius, dkk]

Komponen yang lainnya adalah kartu uang untuk menunjang permainan Teman Plastik. Kartu uang digunakan untuk membeli kartu spesial, pemain dapat mendapatkan kartu uang di awal permainan dan dengan cara mendapatkan kartu plastik beserta sifatnya yang sesuai. Terdapat 37 kartu uang dengan pecahan sebesar 1,2, dan 5 . Terdapat 12 kartu pecahan 5, 10 kartu pecahan 2, dan 15 kartu pecahan 1. Pecahan tersebut dirancang untuk memudahkan pemain dalam menerima hadiah dan bertransaksi kartu spesial. Contoh kartu uang dapat dilihat pada Gambar 9.

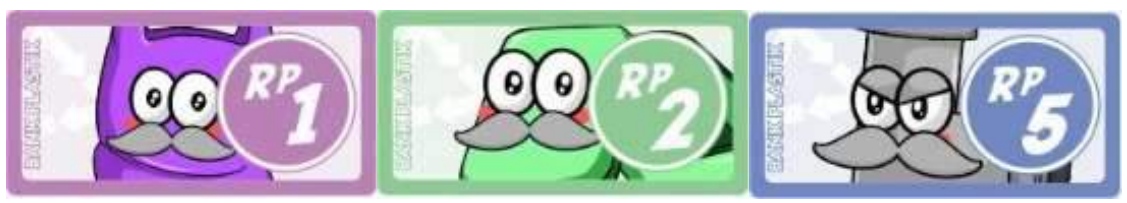

Gambar 9. Hasil akhir kartu uang dalam permainan Teman Plastik [Sumber: Dokumentasi Laurensius, dkk]

Komponen selanjutnya adalah token starter. Token starter berfungsi sebagai penanda giliran pertama dalam putaran permainan yang sedang berjalan. Token starter akan selalu berpindah tangan di setiap akhir putaran. Pemain dengan urutan main terakhir 
dalam putaran tersebut akan menjadi pemain pertama untuk putaran berikutnya, begitu juga setelahnya. Token starter akan selalu berpindah sampai permainan selesai. Contoh token starter dapat dilihat pada Gambar 10.

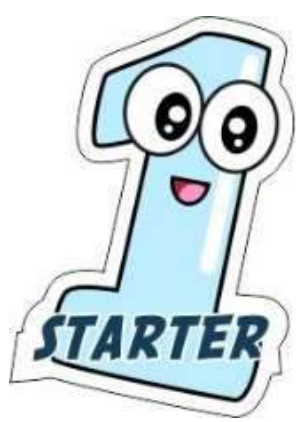

Gambar 10. Hasil akhir token starter dalam permainan Teman Plastik

[Sumber: Dokumentasi Laurensius, dkk]

Komponen terakhir adalah kotak recycle, kotak ini berfungsi sebagai wadah kartu plastik yang sudah didapatkan oleh pemain. Kotak ini terbagi menjadi 2 jenis, yaitu kotak mudah didaur ulang dan sukar didaur ulang. Terdapat 5 buah kotak recycle dalam permainan Teman Plastik. Jumlah tersebut disesuaikan dengan jumlah maksimal pemain, yaitu sebanyak 5 orang. Pemain yang sudah mendapatkan kartu plastik harus memasukkan kartunya ke kotak recycle sesuai dengan sifat plastik yang didapatkan. Kartu plastik yang tidak mempunyai sifat sukar didaur ulang dimasukkan ke dalam kotak berwarna hijau, sedangkan kartu yang bersifat sukar didaur ulang dimasukkan ke dalam kotak oranye. Contoh kotak recycle dapat dilihat pada Gambar 11.

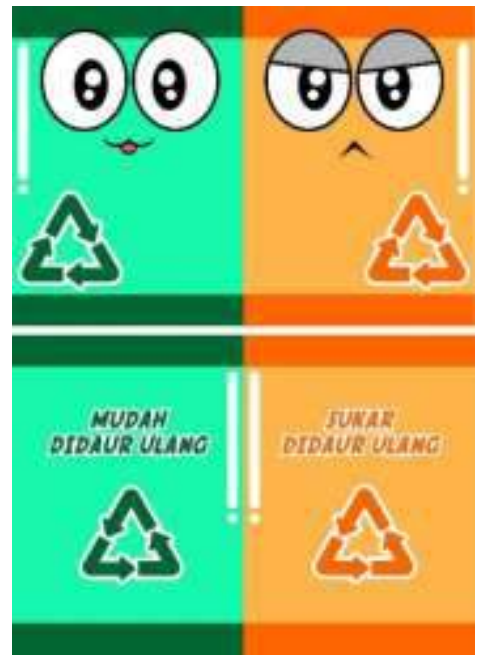

Gambar 11. Hasil akhir kotak recycle dalam permainan Teman Plastik

[Sumber: Dokumentasi Laurensius, dkk]

Tujuan dari permainan ini adalah mengumpulkan kartu plastik dan mendapat nilai sebanyak-banyaknya. Jumlah pemain dalam permainan ini sebanyak $3-5$ pemain, dan durasi permainan berkisar antara 15 - 30 menit. Permainan diawali dengan mengocok kartu plastik dan kartu sifat, lalu menyusun kartu secara tertutup (dianjurkan untuk menyusun kartu plastik dengan format $7 \times 2$, dan kartu sifat dengan format $9 \times 4$ ). Setelah 
itu kartu spesial dikocok dan dibuka sebanyak 3 kartu. Setiap pemain diberi modal sebesar 5 uang plastik guna membeli kartu spesial. Kartu spesial hanya dapat dibeli saat giliran pemain tersebut, dan hanya boleh menyimpan 2 kartu spesial saja. Bagian kosong dari kartu spesial yang dibeli akan selalu dibuka dengan kartu spesial yang masih ada di dek tertutup, sehingga akan selalu ada 3 kartu spesial yang ditawarkan untuk dapat dibeli. Setelah itu tentukan urutan bermain dan berikan token starter pada pemain pertama. Pemain dengan urutan terakhir pada masing-masing putaran akan berganti menjadi pemain pertama dan mendapatkan token starter.

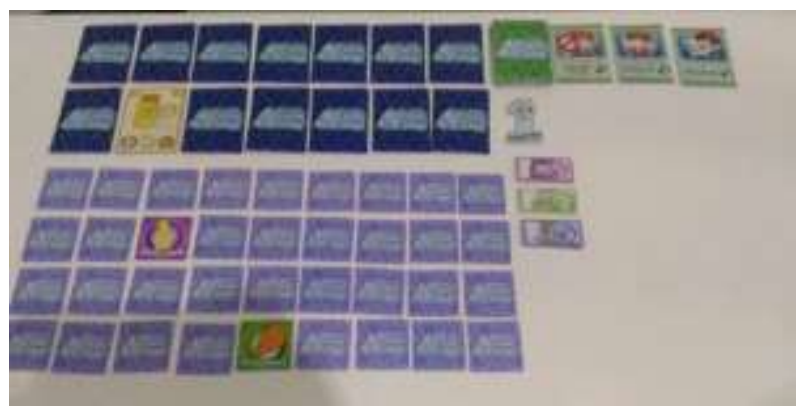

Gambar 12. Tampilan setup permainan Teman Plastik

[Sumber: Dokumentasi Laurensius, dkk]

Cara memainkan permainan ini adalah pertama pemain membuka 1 kartu plastik yang ada, kemudian pemain harus membuka 1 kartu sifat dan mencari sifat yang sesuai dengan kartu plastik yang sudah dibuka. Jika kartu sifat yang dibuka sesuai, maka pemain boleh membuka 1 kartu sifat lagi, tapi jika tidak sesuai semua kartu sifat dan plastik ditutup kembali. Pemain yang berhasil menyesuaikan kartu plastik dan kartu sifat dengan benar akan mendapatkan kartu plastik dan kartu sifat tersebut dan mendapat nilai sekaligus uang plastik yang tertera. Kartu plastik yang sudah diperoleh akan dimasukkan ke kotak recycle yang sesuai dengan sifat plastik tersebut. Permainan berakhir saat semua kartu plastik sudah habis dan pemenang ditentukan dengan jumlah skor terbesar. Tampilan setup permainan dapat dilihat pada Gambar 12, dan kotak permainan dapat dilihat pada Gambar 13.

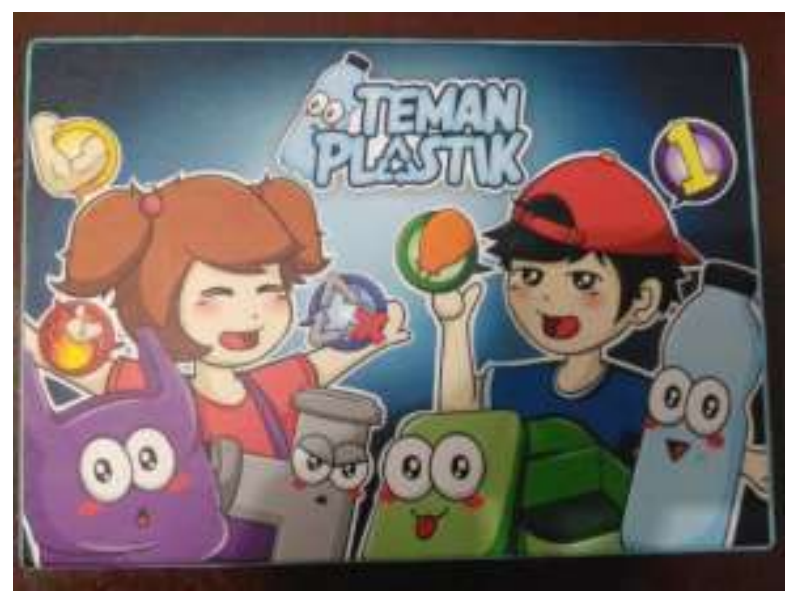

Gambar 13. Tampilan kotak permainan Teman Plastik [Sumber: Dokumentasi Laurensius, dkk] 
Setelah permainan dicetak, permainan siap diujikan pada responden. Siswa kelas V SDN 8 Salatiga akan mengisi 2 kuisioner, kuisioner yang pertama diisi sebelum responden memainkan permainan Teman Plastik, dan kuisioner kedua diisi setelah memainkan Teman Plastik. Hasil dari kuisioner yang telah dijawab responden dapat dilihat pada Tabel 1 dan Tabel 2.

Tabel 1. Hasil kuisioner sebelum responden memainkan Teman Plastik [Sumber: Dokumentasi Laurensius, dkk]

\begin{tabular}{|c|c|c|c|c|c|c|}
\hline No & Pertanyaan & \multicolumn{5}{|c|}{ Jawaban Kuisioner } \\
\hline \multirow[t]{2}{*}{1} & $\begin{array}{l}\text { Apa kamu pernah } \\
\text { memainkan board } \\
\text { game? }\end{array}$ & $\begin{array}{l}\text { Tidak } \\
\text { Pernah } \\
\text { (1) }\end{array}$ & $\begin{array}{c}\text { Jarang } \\
\text { (2) }\end{array}$ & $\begin{array}{l}\text { Sering } \\
\text { (3) }\end{array}$ & $\begin{array}{l}\text { Sering } \\
\text { sekali } \\
\text { (4) }\end{array}$ & Hasil \\
\hline & & 10 & 10 & 2 & 0 & $\begin{array}{c}36 / 88 \times 100 \%= \\
40,9 \%\end{array}$ \\
\hline \multirow[t]{2}{*}{2} & $\begin{array}{l}\text { Bila pernah, dengan } \\
\text { siapa kamu } \\
\text { bermain board } \\
\text { game? }\end{array}$ & $\begin{array}{l}\text { Orang } \\
\text { Tua }\end{array}$ & Teman & Saudara & Lain-lain & Hasil \\
\hline & & 0 & 9 & 3 & 0 & $\begin{array}{c}9 / 12 \times 100 \%= \\
75 \% \text { Teman } \\
3 / 12 \times 100 \%= \\
25 \% \text { Saudara }\end{array}$ \\
\hline \multirow[t]{2}{*}{3} & $\begin{array}{l}\text { Apa kamu sering } \\
\text { menggunakan } \\
\text { plastik? }\end{array}$ & $\begin{array}{c}\text { Sangat } \\
\text { Sering } \\
(4)\end{array}$ & $\begin{array}{l}\text { Sering } \\
\text { (3) }\end{array}$ & $\begin{array}{c}\text { Kadang- } \\
\text { Kadang } \\
(2) \\
\end{array}$ & $\begin{array}{c}\text { Jarang } \\
\text { (1) }\end{array}$ & Hasil \\
\hline & & 4 & 9 & 7 & 2 & $\begin{array}{c}59 / 88 \times 100 \%= \\
67 \%\end{array}$ \\
\hline \multirow[t]{2}{*}{4} & $\begin{array}{l}\text { Apa kamu pernah } \\
\text { melihat lambang } \\
\text { plastik? }\end{array}$ & \multicolumn{2}{|c|}{ Pernah } & \multicolumn{2}{|c|}{ Tidak Pernah } & Hasil \\
\hline & & \multicolumn{2}{|c|}{11} & \multicolumn{2}{|c|}{11} & $\begin{array}{c}11 / 22 \times 100 \%= \\
50 \% \text { Pernah } \\
11 / 22 \times 100 \%= \\
50 \% \text { Tidak } \\
\text { Pernah }\end{array}$ \\
\hline \multirow[t]{2}{*}{5} & $\begin{array}{l}\text { Apa kamu mengerti } \\
\text { mengenai lambang- } \\
\text { lambang plastik? }\end{array}$ & $\begin{array}{c}\text { Sangat } \\
\text { Mengerti } \\
(4)\end{array}$ & $\begin{array}{l}\text { Cukup } \\
\text { Mengerti } \\
(3)\end{array}$ & $\begin{array}{c}\text { Kurang } \\
\text { Mengerti } \\
(2) \\
\end{array}$ & $\begin{array}{c}\text { Tidak } \\
\text { Mengerti } \\
(1) \\
\end{array}$ & Hasil \\
\hline & & 0 & 4 & 6 & 12 & $\begin{array}{c}36 / 88 \times 100 \%= \\
40,9 \%\end{array}$ \\
\hline
\end{tabular}

Dari hasil kuisioner pertama diperolah data bahwa 40,9\% atau sebanyak 12 responden pernah memainkan board game. Dari 12 responden yang pernah bermain board game diketahui bahwa $75 \%$ responden bermain bersama teman-temannya, dan $25 \%$ responden bermain bersama saudaranya. Responden yang sering menggunakan plastik sebesar $67 \%$. Sebanyak $50 \%$ responden pernah melihat lambang plastik, dan 50\% sisanya menyatakan belum pernah melihat lambang plastik. Sebanyak $40,9 \%$ responden 
mengerti mengenai lambang-lambang plastik yang ada. Dari hasil tersebut, dapat disimpulkan bahwa responden belum terlalu mengenal board game dan sering menggunakan plastik dalam kehidupan sehari-hari. Hal ini menjadi pendukung yang baik untuk penelitian lebih lanjut.

Tabel 2. Hasil kuisioner setelah responden memainkan Teman Plastik [Sumber: Dokumentasi Laurensius, dkk]

\begin{tabular}{|c|c|c|c|c|c|c|c|}
\hline \multirow[b]{2}{*}{ No } & \multirow[b]{2}{*}{ Pertanyaan } & \multicolumn{6}{|c|}{ Jawaban Kuisioner } \\
\hline & & $\begin{array}{l}\text { Sangat } \\
\text { Setuju (5) }\end{array}$ & $\begin{array}{l}\text { Setuju } \\
(4)\end{array}$ & $\begin{array}{l}\text { Ragu- } \\
\text { Ragu } \\
\text { (3) }\end{array}$ & $\begin{array}{c}\text { Tidak } \\
\text { Setuju } \\
(2)\end{array}$ & $\begin{array}{c}\text { Sangat } \\
\text { Tidak } \\
\text { Setuju } \\
\text { (1) }\end{array}$ & Hasil \\
\hline 1 & $\begin{array}{l}\text { Apa permainannya } \\
\text { mudah untuk } \\
\text { dimainkan? }\end{array}$ & 20 & 2 & 0 & 0 & 0 & $\begin{array}{c}108 / 110 \\
\times 100 \% \\
=98 \%\end{array}$ \\
\hline 2 & $\begin{array}{l}\text { Apa permainannya } \\
\text { menyenangkan? }\end{array}$ & 20 & 2 & 0 & 0 & 0 & $\begin{array}{c}108 / 110 \\
\times 100 \% \\
=98 \%\end{array}$ \\
\hline 3 & $\begin{array}{l}\text { Apa gambar dan } \\
\text { warna kartunya } \\
\text { bagus? }\end{array}$ & 19 & 3 & 0 & 0 & 0 & $\begin{array}{c}107 / 110 \\
\times 100 \% \\
=97 \%\end{array}$ \\
\hline 4 & $\begin{array}{l}\text { Apa kamu ingin } \\
\text { memainkan } \\
\text { permainan ini lagi? }\end{array}$ & 21 & 1 & 0 & 0 & 0 & $\begin{array}{c}109 / 110 \\
\times 100 \% \\
=99 \%\end{array}$ \\
\hline 5 & $\begin{array}{l}\text { Apa kamu jadi } \\
\text { mengerti jenis-jenis } \\
\text { plastik setelah } \\
\text { bermain? }\end{array}$ & 15 & 7 & 0 & 0 & 0 & $\begin{array}{c}103 / 110 \\
\times 100 \% \\
=93 \%\end{array}$ \\
\hline 6 & $\begin{array}{l}\text { Apa kamu jadi } \\
\text { mengerti sifat-sifat } \\
\text { plastik setelah } \\
\text { bermain? }\end{array}$ & 20 & 2 & 0 & 0 & 0 & $\begin{array}{c}108 / 110 \\
\times 100 \% \\
=98 \%\end{array}$ \\
\hline 7 & $\begin{array}{l}\text { Apa kamu tertarik } \\
\text { untuk belajar lebih } \\
\text { banyak tentang } \\
\text { plastik? }\end{array}$ & 15 & 7 & 0 & 0 & 0 & $\begin{array}{c}103 / 110 \\
\times 100 \% \\
=93 \%\end{array}$ \\
\hline
\end{tabular}

Dari hasil kuisioner kedua diperolah data bahwa 98\% responden menganggap permainan mudah untuk dimainkan. Sebanyak $98 \%$ responden menganggap bahwa permainannya menyenangkan. Gambar dan warna dari permainan Teman Plastik dianggap bagus oleh $97 \%$ responden. Sebanyak $99 \%$ responden ingin memainkankan permainan lagi. Sebanyak 93\% responden menjadi tahu akan jenis-jenis plastik, dan 93\% responden menjadi tahu akan sifat-sifat plastik. Sebanyak $93 \%$ responden tertarik untuk belajar lebih mengenai plastik. Dari data tersebut dapat disimpulkan bahwa respon dari responden terhadap penelitian ini sangat baik, dan responden menjadi lebih paham mengenai jenis-jenis plastik beserta sifatnya. 
Berdasarkan data yang diperoleh, dapat disimpulkan bahwa banyak responden yang masih belum mengenal board game. Hal ini menjadikan penelitian ini dapat menjadi media yang baru bagi responden untuk bermain sekaligus belajar. Banyak responden yang sering menggunakan plastik dalam kesehariannya, dan sebagian tidak pernah melihat lambang plastik dan kebanyakan belum mengerti mengenai lambang-lambang plastik yang ada. Penelitian ini dinilai mampu sebagai media pengenalan jenis-jenis plastik untuk anak-anak berdasarkan data tersebut. Responden merasa permainannya mudah dan menyenangkan. Tingkat replayability dalam permainan ini juga dinilai tinggi, karena responden ingin memainkan permainan ini berulang-ulang. Responden juga lebih mengerti akan jenis-jenis plastik beserta sifat-sifatnya setelah bermain, dan antusias responden untuk belajar lebih tentang plastik juga dinilai baik.

Hasil wawancara dengan Munawiati menyatakan bahwa media yang dapat memaksimalkan penggunaan panca indera lebih diminati murid-murid daripada sekedar duduk dan mendengarkan di kelas. Daya ingat murid-murid lebih terangsang menggunakan media visual dibandingkan penjelasan secara lisan. Antusiasme muridmurid terhadap media pembelajaran kreatif sangat tinggi, terutama ketika permainan Teman Plastik diujikan kepada murid-mutid. Munawiati berharap seluruh mata pelajaran yang ada mempunyai permainan edukatifnya masing-masing, karena permainan edukatif dapat membantu guru untuk proses belajar mengajar. Munawiati juga berharap adanya pelatihan untuk guru-guru supaya dapat lebih memahami permainan edukatif dan mengajarkan murid-murid untuk bermain dan belajar di sekolah. SDN 8 Salatiga sangat terbuka dengan berbagai media pembelajaran kreatif yang ada dan berharap suatu saat memiliki perangkat media pembelajaran kreatif sendiri. Dari hasil wawancara tersebut, dapat dianalisa bahwa game juga bisa menjadi media pembelajaran untuk menunjang proses belajar mengajar. Terutama karena game dapat memaksimalkan panca indera murid-murid saat proses belajar dan merangsang daya ingat anak.

\section{KESIMPULAN}

Setelah terbiasa melakukan kegiatan belajar mengajar dengan cara yang biasa dilaksanakan di sekolah, anak-anak merasakan antusiasme yang besar untuk mencoba media pembelajaran menggunakan permainan edukatif di sekolah. Permainan edukatif dinilai lebih menarik dan menyenangkan untuk anak-anak dan bagus untuk merangsang indra-indra yang ada pada tubuh anak-anak. Anak-anak dapat mengenal jenis-jenis plastik yang ada beserta sifat-sifatnya. Anak-anak dapat mengurangi penggunaan plastik sekali pakai, dan mengetahui jenis plastik yang sulit untuk didaur ulang. Sifat sportif dan jujur juga ditunjukkan selama permainan berjalan, saling menghormati tanpa ada yang menyerobot giliran permainan. Penelitian ini dinilai dapat menjadi media pembelajaran untuk anak-anak dengan cara yang menyenangkan dan mudah.

\section{DAFTAR PUSTAKA}

Christian, Imanuel Vicky \& Prasida, Arie Setiawan. 2018. Developing board game as learning media about waste sorting for fourth grade students of elementary school. Jurnal Prima Edukasia, 6 (1), 2018, 78-88. 
Hijriati. 2017. Peranan dan Manfaat APE Untuk Mendukung Kreativitas Anak Usia Dini. Bunayya Jurnal Pendidikan Anak, 3(2), 59-69.

Jordi, Dede. 2017. Perancangan Board Game Edukatif Tentang Peduli Lingkungan Untuk Anak Usia 7-12 Tahun.

Karuniastuti, Nurhenu. 2013. Bahaya Plastik terhadap Kesehatan dan Lingkungan. Jurnal Swara Patra: Majalah Pusdiklat Migas, 3(1), 6-14.

Likert, Rensis. 1932. "A Technique for the Measurement of Attitudes", Archives of psychology.

Nugroho, Eko. 2013. Game Design Process. (Updated 22 Agustus 2013) URL: https://www.slideshare.net/kummara/game-design-process-2013-kummara [diakses pada 17 Juli 2018].

Nurhayati. 2018. Pentingnya Pendidikan Karakter Bagi Siswa Sekolah Dasar. (Updated $26 \quad$ Oktober 2018) URL: https://www.kompasiana.com/nurhayati1/5bd273abc112fe079c7bdb74/pent ingnya-pendidikan-karakter-bagi-siswa-sekolah-dasar?page=all [diakses pada 1 November 2018].

Sarwono, Jonathan, dan Hary Lubis. 2007. Metode Riset Untuk Desain Komunikasi Visual Edisi I. Yogyakarta. CV Andi Offset.

Setiawani, Mary Go. 2001. Pembaruan Mengajar Edisi I. Bandung. Yayasan Kalam Hidup. Sudarsana, I Ketut. 2017. Membentuk Karakter Anak sebagai Generasi Penerus Bangsa Melalui Pendidikan Anak Usia Dini. Jurnal Purwadita, 1(1), 41-48.

Sugiyono. 2014. Metode Penelitian Kombinasi (Mixed Methods), Edisi ke-5. Bandung. Alfabeta.

Syafputri, Ella. 2014. Produksi Sampah Plastik Indonesia 5,4 Juta Ton per Tahun. (Updated 4 Februari 2014) URL: http://www.antaranews.com/berita/417287/produksi-sampah-plastikindonesia-54-juta-ton-per-tahun [diakses pada 17 Juli 2018].

Tangidy, Allez Martin \& Setiawan, T Arie. 2016. TOLERANSI MELALUI MODEL BUDAYA PELA GANDONG Menggunakan Media Board Game untuk Mahasiswa. Sabda : Jurnal Kajian Kebudayaan, 11(2), 16-25.

Wawa. 2012. Lamanya Konsentrasi Si Kecil Bergantung Usia. (Updated 22 Mei 2012) URL:

https://lifestyle.kompas.com/read/2012/05/22/07325742/Lamanya.Konsentr asi.Si.Kecil.Bergantung.Usia [diakses pada 17 Juli 2018].

Widodo, Asmar Wono \& Syarif, Arry Maulana. 2014. Iklan Layanan Masyarakat Bahaya Sampah Plastik.

Wirawan, Adhicipta R. 2015. Pemanfaatan Board Game dan Card Game dalam Pembelajaran. (Updated 27 Desember 2015) URL: http://www.adhicipta.com/liburan-di-rumah-dengan-boardgame/ [diakses pada 17 Juli 2018].

Wright, Thomas. 2017. Bagaimana Indonesia bisa melawan pencemaran plastik. (Updated 5 September 2016) URL: https://theconversation.com/bagaimanaindonesia-bisa-melawan-pencemaran-plastik-81558 [diakses pada 17 Juli 2018]. 